Historic, archived document

Do not assume content reflects current scientific knowledge, policies, or practices. 



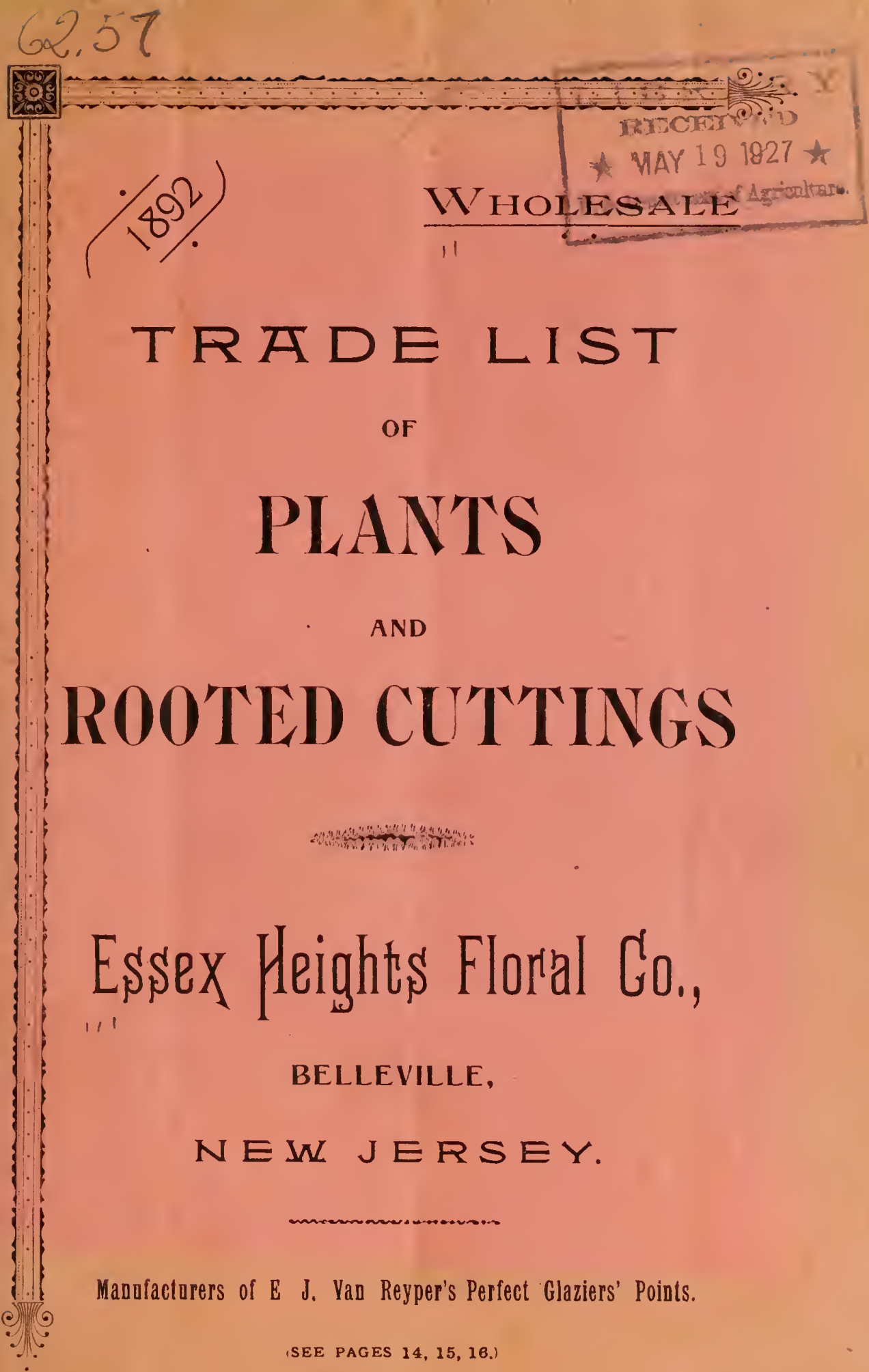




\section{TO THE TRADE.}

WE make Carnations one of our specialties, having a stock of over 35.000 bluoming plants; they are grown in a low tensperature and we can guarantee good heaithy stock. We have also a large stock of other plants and ronted cuttings so that where a quantity is required we can make a low figure.

We issue no retail catalogue.

Terms Cash, unless otherwise agreed upon.

Unknown Correspondents. Orders from unknown correspondents must be accompanied with cash or satisfactory reference, we make no deviation from this rule, as at the very low rates offered, we cannot afford to run any risk.

C. O. D. Orders. Orders to be shipped by express, C. O. D. must be accompanied by onefourth the amount of such in cash.

Remittance. Money should be sent in the form of a bank draft, money order, express order - or registered letter; remittance in any other way is entirely at the senders' risk.

Plants by Mail. We make the mailing of rooted cuttings a specialty, so that parties in far off points who wish to avoid express charges may add ten cents per hundred, or for plants add one-fifth of the cost of plants and have them sent by mail.

Shipping. All goods sent by express unless otherwise ordered. We ean ship by Well : Fargo \& Co., Adams or United States Express and guarantee the safe arrival of all shipments. Invoice mailed the day the plants are shipped.

Packing. This will be done in the best manner and as light as possible. No charge for boxes, baskets or packing.

Forwarding. Every order is executed at once on its receipt, or a reason given why it has not been sent, so that parties ordering may know that if goods are not received in proper time it is almost certain that their letter has not been received by us.

Name and Address. Please write your Name, Post Office, County and State as distinctly as possible, especially the name; also the nearest Express Office.

Our Greenhouses. In area, our Greenhouses occupy 60,000 square feet in solid glass; they are heated by steam that an even, natural temperature can be maintained, and thus the most perfect bealth, strength and vigor is given to the plants.

The Greenhouses may be reached in forty minutes from New York by the Erie R. R. to Essex station; by the Penn. R. R., Del., Lack. \& W. R. R., Lehigh Valley R. R. or the Central R. R. of N. J, to Newark; then take the Broad Street Horse Cars to Belleville to the end of the line.

We shall be pleased to see any one of our patrons, and invite an inspection of our Stock at all times.

\section{ESSEX HEIGHTS FLORAL CO.,}

BELLEVILLE,

EDWIN J. VAN REYPER, Manager.

NEW JERSEY. 


\section{CARNATIONS.}

\section{SEEDLINGS OF I892.}

Anrora-The winner of the Ladenburg cup at Madison Square Garden, New York, on November $6 \mathrm{th}, 1891$. Flowers are a delicate pink, a tritle larger than Wilder, with delightful fragrance. It is a strong grower, coming into bloom quickly. We had the pleasure of seeing the bunch that won the cup in New York and can assure our patrons that it is a grand carnation for its color, fragrance and foliage, and one that will be in demand.

Thos. Cartledge-Carmine pink, similar to Le Purite, A very strong robust grower, early to come in flower; very prolific.

Grace Darling-An exquisite pure pink; slightly darker than Wilder, flowers large, on long stems and never burst their calyx. It is a vigorous grower, of medium size, and an early and profuse bloomer.

Crimson Coronet-Flowers deeply fringed, fine shade of crimson; good size and form. Very healthy, fragrant, and a medium sized grower.

Peachblow Coronet-Flower a beautiful peach pink. Growth the same as Crim= son Coronet.

Golden Triımph-New yellow; canary yellow flowers, extra large, does not burst its calyx. A free bloomer with no tendency to crop. Plants are healtly and rigorous, of medium height. Flowers are on large stiff stems and are well adapted for shipping.

$\$ 2.00$ per doz. \$12.00 per roo. \$100 per rooo.

Dorinda-The plant is healthy and vigorous, medium height, it flowers early; it is also of excellent habit. The flower is a pleasing shade of pink, a trifle darker than "Wilder," but very much softer than "Tidal Wave." The flowers are very large, finely fringed and mostly produced on long stens, very free, and does not burst its calyx. Its keeping qualities are remarkable. It is very fragrant.

Rooted Cuttings, $\$ 8.00$ per 100. $\$ 75.00$ per rooo. Plants in $2 \frac{1}{4}$ in. pots, $\$ 3.00$ per doz. $\$ 10.00$ per roo. $\$ 80.00$ per rooo.

Pearl-White, very large; f requently from three to three and one-lialf inches across, full and crisp; occasionally a rosy blush with rarely any tendency to burst. A good bloomer, stems long and stiff. A very strong flower that will command an extra price; awarded honorable mention at Philadelphia, and Certificate of Merit at New York exhibition in spring of 1891.

$\$ 1.50$ per doz. \$10.00 per 100. $\$ 80.00$ per rooo.

Puritan - White, large, very full and of good substance, lasting if well grown a long time after being cut. It is quite fragrant, and an early and continuous bloomer.

$\$ 1.20$ per doz. \$8.00 per 100. \$70.00 per 1000 .

\section{NOVELTIES.}

Angelus-Flowers semi-double, of a fine shade of pink, rather darker than Grace Wilder. It is medium early and of tall growth.

Dorothy-Habit of plant similar to Angelus but not quite as tall. Flowers of a darker shade of pink and more deeply fringed. Medium early.

Nellie Bly-Flowers uredium large, semi-double; variegated red and white in almost even narrow stripes, and finely fringed. Growtli tall.

Gen. Custer-Another variegated sort, but red predominating, and finely marked: a prolific but late bloomer. Tall in growtl.

$80 \mathrm{cts}$. per doz. $\$ 6.00$ per 100.

Ohio-The flowers are borne on stiff, erect stems; pure white, extra large and finely fringed, centre very full. The habit of the plant is a dwarf and well branched; it is a healthy, robust grower and free bloomer.

Snow Bird-Very large fringed white, fragrant, continual bloomer, long stenis, never bursts its calyx. One of the finest white carnations yet produced.

White Wings-(E. B. Jennings)-A splendid, free flowering, large pure white: extra strong, robust grower, with handsome foliage. 


\section{NOVELTES-Continued.}

Day Break-Flowers are large and perfect in form. A beautiful, delicate, pure bright flesh color and is entirely distinct from any other variety now under cultivation. The growth of the plant is strong and robust.

Orange Blossom-Color white with pink centre; far superior to Dawn. Flowers on long stems, never bursting the calyx. Splendid grower, free bloomer.

Amy Phipps-Flowers large golden yellow with crimson markings. A free bloomer and strong, healthy grower.

La Creme-Large flower, French white, slightly edged with purple.

Imerican Flag-A sport of Portia. One of the best striped carnations ever produced.

G. C. Tyler-A splendid variegated variety. A strong grower with very large flower. 75 cents per doz. $\$ 5.00$ per 100 .

Lizzie McGowan-The largest and best white carnation under cultivation; it never bursts its calyx. Flowers are large, glossy white, measuring two and one half to three inches. They may be grown closer together than other varieties, being of strong, straight, upright growth. Do not be without it if you grow cut flowers ; it is a grand keeper.

Edelveiss-This is an excellent variety with us. Flowers are large and of the purest white. It is a sport of Chester Pride, and a good, strong, healthy grower.

Golden Gates-New pure yellow; a good bloomer and extremely strong grower.

Wil. F. Dreer-Flowers fringed rose pink ; a magnificent addition to pink carnations. A very strong grower.

J. R. Freeman-Flowers cardinal and finely fringed; healthy and free flowering. Clove scented.

Constancy - A beautiful, bright glowing scarlet. Flowers large and finely fringed. Very prolific with long stems. An excellent grower.

Hector-A brilliant, dazzling scarlet, flower large. A free, continuous bloomer and strong, healthy grower. A first-class sort.

May Flower-A beautiful variegated variety, large flower. A robust grower.

Nellie Lewis-A sport of J. J. Harrison and has the same growth as its parent. It is free flowering; the flowers being very large, delicate pink deeply marked with carmine.

Ella May Fuller-A lovely carnation: free 'grower and good bloomer. Color, a bright madder rose edged with white.

Chester Pride-Flowers white striped with pink and carmine, rarely burst; a strong grower and profuse bloomer.

Louise Porsch-A very fine yellow streaked with carmine and fringed. Flowers are large, on long stems, and do not burst their calyx. A free bloomer, strong grower and a very desirable carnation.

Dawn-Pure white with deep blush or pink centre. Flowers are large, handsome and very fragrant.

\section{0 cts. per doz. $\$ 3.00$ per roo. $\$ 25.00$ per I000.}

\section{STANDARD VARIETIES.}

Grace Wilder-One of the most beautiful colors among carnations. A soft shade of pink, free and continuous bloomer, strong grower, and flowers always on long stems.

Mrs. Cleveland-A soft shade of carmine, very fine and prolific. Flowers large and on long stems.

May Queen-Dark pink, good sized flower on long stems ; very prolific and strong grower.

Portia-The finest dazzling scarlet; a splendid sort. Flowers fringed and produced in the greatest abundance on long stems. Beautiful in habit and foliage.

Lady Emma-One of the finest scarlets, very early and a strong grower.

John McCullough-Flowers of good form, never bursting. A very healthy grower and most continuous bloomer. One of the best brignt vermillions we have seen.

Philadelphia Red-An old variety; we grow it for its good qualities. A bright scarlet, strong grower and profuse bloomer.

Hinze's White-A very heavy cropper; flowers creamy white, extra large.

Silver Spray-Flowers are large, of good form and freely produced on long stems. An early and continuous bloomer and strong grower, of medium height. 


\section{STANDARD VARIETIES-Continued.}

Mr:s. Fisher-One of the finest of white carnations, being a vigorous grower, a free and continuous bloomer. Flowers are large, on long stems and never burst. Also a good carnation for blooming outside in summer.

White Grace WVilder-A sport of pink Grace Wilder, a strong grower, very prolific; flowers pure white, medium size, on long stiff stems.

Orient-Deep crimson, very large, highly fragrant flowers. A dwarf, compact grower; good variety for side benclies.

Garfield-Crimson scarlet; extra large flower. A dwarf grower.

$\$$ I.50 per roo. \$12.50 per 1000.

Tidal Wave-A grand addition to the cut flower trade. The color is a very bright pink shaded salmon when first open, growing somewhat lighter when fully expanded. A very healtlyy dwarf grower and remarkably free bloomer; flowers are large and perfectly shaped.

J. J. Harrison-The finest cut flower carnation ever sent out, and is justly called by some "The Pink of Perfection." Flowers are large, of perfect form and freely produced. Color, pure white, delicately marked and shaded pink. It is one of the best selling varieties in New York market.

Hinsdale-White, tinted, streaked and laced with delicate pink; very free flowering. A most desirable sort.

Columbia-Color deep buff, shaded with orange with crimson markings. Good grower; flowers on long stems.

Grace Farden-A little darker pink than Grace Wilder; vigorous grower and very prolific all the season.

Century-Of healthy growth, medium height and an early and constant bloomer; color, glowing carmine with a richclove fragrance.

Tendresse-Lovely bright pink flowers of medium size and perfect form, never bursting.

Beauty of Oxford-Color same as Grace Wilder. A good keeper, always retaining its beautiful color after being cut.

Ferdinand Mangold-Flowers large and deeply fringed dark red, a good strong grower, first class carnation.

Christmas-A trifle darker in color than Wilder and a little stronger growth; an excellent sort.

Pride of Kennett-A deep, rich crimson; flower of good size, fragrant and borne on a long, stiff stem, never bursting its calyx, (first class).

Fred Creighton-An improvement on Grace Wilder, being a much stronger grower; color, de!icate pink.

Alexandria-A beautiful deep, rose pink. Good grower, and flowers freely produced. Constantly in demand for cut flowers.

Mrs. F. Mangold-A beautiful salmon pink borne on long, stout stems. A great acquisition in pink color and a robust grower.

Brilliant-Color, vermillion. Grown a great deal on Long Island.

L. L. Lamborn-A dwarf, compact grower, adapting it for side benches. Flowers very large and of the purest white, all on long stems.

$\$ 2.00$ per 100. $\$ 15.00$ per 1000 .

\section{BEST NEW CHRYSANTHEMUMS.}

The following varieties are the best New Chrysanthemums for cut flower and exhibition purposes. We have taken special pains to select only tliose which were superior in size, beanty and habit, and which are sure to give satisfaction.

Mrs. D. D. Farson-Unquestionably the most meritorious introduction of the year. Size immense, solid and compact, color bright mermet pink. Winner of Pitcher Cup, and Silver Medal of Pennsylvania Horticultural Society, and medal at American Institute.

Clancy Lloyd-Delicate flesh pink changing to pure white, incurved. Received medal of excellence at the American Institute.

Mrs. Kendal-A fine Japanese flower with compact centre. Color rich Jacqueminot red; reverse of petals coppery bronze. 


\section{BEST NEW CHRYSANTHEMUMS-Continued.}

Mattie C. Stewart-Clear bright golden yellow, extra large and double. Petals broad and flat, reflexing with age. High built bloom. Winner of Silrer Cup at Indianapolis.

Lizzie Cartledge-Very. large full double flower, incurved except under row of petals which reflex. Color bright dark rose, reverse silvery white.

Progression-Extra large late flowering variety, blooming about December 1st and remaining in flower up to Christmas. Color purest white, rery double in style of Grandiflorum.

Anna M. Weybrecht-A magnificent Chinese variety of purest snow white, petals solid, broad and firm; of strong habit. Awarded Silver Medal.

Mrs. R. J. Baylis-An immense incurving Japanese bloom. Color clear yellow striped and highly marked red, bronze and gold. Said to be the largest flower of any Chrysanthemum.

Lilly Bates-Very large perfectly double clear bright rich pink, petals broad and flat, new and distinct form. Winner of the Pitcher Cup, Certificate at Indianapolis and Medal at American Institute.

John Firth-This variety has won a number of Certificates, Medals and Cups and is one of the best show rarieties. Deep mermet pink shading to silvery rose.

Mrs. Lay-Petals cup shaped: white with the faintest blush lines on edges; extremely double; pyramidal rather than globular in shape. Awarded Silver Medal by Pennsylvania Horticultural Society.

Chas. Canfield-Extra large and full; double incurred bloom of robust habit. Color claret red, reverse silvery pink.

Lyman J. Gage-A late white cut flower variety, of perfect incurved form.

George R. Davis-Flowers finely incurved of the "Wheeler" type. Color blood red lined with gold.

Fred S. Winston-A fine variety of beautiful bronzy cardinal color witl reverse of Indian red.

Cyrus $\mathrm{H}$. McCormick-This is an unusually vigorous grower, bearing massive flowers of the shape and make up of "W. H. Lincoln." Color deep yellow shaded with bronze red. A promising sort.

Andrew $\mathrm{McNally}$-Crimson scarlet in color with reverse of old gold ; very brilliant and beautiful.

Charles T. Yerkes-Very regular, high incurved form, color bright scarlet and gold.

Ferd W. Peck-Another of the six varieties that won the $\$ 100$ prize at Indianapolis. The color is a most beautiful rosy pink, petals incurving.

J. V. Farwell-One of the six that won the $\$ 100$ prize at Indianapolis. In form it is finely incurved, having rery broad concave petals of great substance. The color, silvery lavender without and beautiful rosy pink within, velvety texture.

Charles H. Wacker-Flowers medium to large, brilliant crimson scarlet.

Robert A. Waller-The color is a beautiful shade of chamois yellow, flowers perfectly double.

S. W. Allerton-A large flowered, extra good white variety. A large, bold, pure white flower that at once pleases the eye. Of sturdy, bushy growtl. Will nake a fine pot or exhibition sort.

Potter Palmer-A splendid white seedling from "L. Canning." A strong fine grower carrying its flowers on long stems.

Yonitza-Chinese incurved, late, fine for Christmas flowers, color white.

Alcazar-Incurved Japanese. Robust habit, flowers on strong stems, upper smrface of petals bronze red, shading on yellow at the tips with reverse of old gold.

Aristine Anderson-Resembling "Miss Mary Morgan" but an improvement on that variety, being a more decided pink and larger blooms.

Oeta-Chinese incurved of most perfect form, color canary yellow with outer petals of striped rose.

Robert Flowerday-Japanese. Large bold flowers and foliage, outer petals flat with centre incurving, upper surface bright crimson lake, reverse silvery pink.

Mrs. J. Lewis Childs-A first-class cut flower variety blooming even later than "Christnaas Eve." Flowers of enormous size of the incurved Japanese type, nearly as round as a ball and as white as snow.

Mistletoe-A large size of the incurved Japanese type, corering up the centre entirely. Color rich crimson with silvery reflex. The prize winner at Indianapolis; 1890. 


\section{BEST NEW CHRYAANTHEMUMS-Continted.}

Anna Dorner-1 fine bold flower with outer petals striped and shaded deep carmine, centre a rich creamy white. Received Certificate of Merit.

Eda Prass-A fine bold recurving flower of great substance and depth, when opening of a delicate salmon color, then changing to a creany white delicately shaded blush. Certificate of Merit.

Mermaid-Very beautiful soft pink with deeper shadings, most perfectly incurved. Received Certificate of Mrerit.

Evaleen Stein-Petals like the variety "Elkshorn," but of a delicate white color. Received Certificate of Merit.

Innocence-The form is incurved like " $\mathrm{H}$. Cannell," said to be the purest of all white varieties. Received Certificate of Merit.

Emma Dorner-A tine deep violet pink in the way of "Violet Rose" but of a much deeper and richer color. Received Certificate of Merit.

Frank Thomson-A splendid flower nearly spherical in form, petals very broad and heavy and finely incurving. It is very nearly white in color, only showing a touch of pearl pink at the base of the petals, Receired First-Class Certificate.

Mrs. I. D. Sailer-A flower of the largest size, finely incurving with broad sharply pointed petals, strong grower, producing heavy flower stems. The color is a soft shell pink touched with lemon on the extreme tips of petals. Winner of the Sailer Cup at Philadelphia.

John Goode-A good cut flower variety, it is ahmost globular in form, of the finest silky finish and destined to become a standard sort for cutting. The outer petals are delicate lavender, forming a decided band of color, the inner petals are clear lemon.

C. W. Depauw-This was produced by the raiser of "Widener." It is a very double sort, having long petals arranged in most perfect form. The color is a soft pearl pink with touches of light lavender.

R. Maitre-Flowers of the largest size. perfectly double and without a trace of coarseness. Color, the finest pink, a splendid keeper and a thrifty grower. One of six that took the $\$ 100$ prize at Philadelphia.

Sugar Loaf-A very robust variety, color yellow, often shaded bronze. One of the best varieties yet introduced.

Emily Dorner-Petals incurred and of the richest shade of orange yellow touched with crimson.

Elmer D. Smith-Flower extra large and foliage very heavy and green, color is cardinal red of a very rich pleasing shade, faced upon the back of the petals with clear chanois.

Mrs. Herbert A. Pennock-Yellow violet rose. This is perhaps the greatest novelty of the new chrysanthemums. It is similar in habit and shape to "Violet Rose."

Mrs. John Westcott-Color varies from creamy white to creamy pink. Flowers enor'mous, reflexed.

Mary Waterer-A grand novelty in a delicate shade of beautiful rose.

Eldorado-A most lovely incurved deep yellow, of beautiful form possible. The richest color of all yellows when grown with some heat; large in size.

Kate Ramboy-Pure white, very large, broad, double flower, incurved slightly. A very robust, yet compact grower with fine stout stems.

Md. Ferd Bergmann-The finest early sort. Full, round flowers of perfect form, color" pure white.

M. Victor Patallier-Very large, perfectly flat and very double. Bright yellow.

Sabine Mea-Bright golden yellow, perfectly double and almost globular in form.

Mrs. Falconer Jameson-Enormous blooms of chestnut bronze of very pleasing shade, richer than "W. W. Coles," high centre, plants of good habit.

Rose Laing-Spiral centre of heliotrope pink, outer petals recurving, of blush white, faced with white underneath.

Cesare Costa-Very large flat flower of dark velvety red.

Cleopatre-Very large and pure white, of soft plumy appearance.

Stanstead White-Large petals, incurved, pure white. Received three first.class certificates at the English shows.

Sunflower-It is a flower of massive character, broad, solid and of a brilliant yellow color.

Eynsford White-Awarded a first-class certificate hy the Royal Horticultural Society, and also one by the National Chrysanthemuin Society. It has broad irory white petals, and is the best and most solid white yet sent ont. 


\section{BEST NEW CHRYSANTHEMUMS-Continued.}

Robert Cannell-A beautiful incurred variety. Flowers measure $5 \frac{1}{2}$ inches in width, it is faultless. Color a rich chestnut red, the upper surface of the petals deep bronzy gold.

White Cap-Exquisite whiteness, short, broad petals, incurving, making a perfect ball.

Charity-Bright rosy carmine, shading very light towards ends of petals and centre of flower, which is six inches across. Petals somewhat convex and slightly incurved towards centre, outer row drooping. The brightest carmine.

Louis Boehmer-Strong grower, large violet pink flowers that are coveresl with velvety pile, in the style of Mrs. A. Hardy.

Mrs. Alpheus Hardy-The white Ostrich Plume.

Rooted Cuttings per roo, $\$ 6.00$

From $2 \frac{1}{2}$ inch pots per 100, $\$ 10.00$

\section{GENERAL COLLECTION.}

Our collection of older varieties are all good-sized flowers, well tested for cut flower purposes. It also contains all the best show sorts which are handsome early bloomers.

L. Canning-One of the most useful Chrysanthemums yet raised. Flowers pure white, large. Plant dwarf and compact.

Cullingfordi-Brilliant crimson, back of petals golden yellow, well reflexed. late.

M. De launoy-Flowers large and double, light canary yellow shading to white,

Lady St. Clair-One of the most beautiful of the incurved type, large flowers of the purest snow white.

Grand Mogul-Flowers large, violet amaranth, reverse of petals, white Lili Baltet. White with rose centre, reverse cream, medium size.

Bras Rouge-Flowers medium size, rich bright velvety crimson and maroon, free and early.

Mon. H. Elliot-Yellow and bronze color.

Elsie-A very free reflexed variety that is quite useful for cut flowers, pale canary passing to creamy white with age.

Robert Bottomly-Very desirable sort of splendid habit, large pure white.

Hon. John Welsh-Rich crimson amaranth, semi-double.

Petit Antonin-Flaming rose pointed with clear rose, free and good.

Lady Matheson-Very large petals, rosy white at the borders, centre creamy color. An excellent late bloomer.

Le Chevrefeuille-Petals spiral, yellow honeysuckle color.

Gloriosum-Bright lemon yellow, early. One of the best for cut flowers.

Geo. W. Childs-Dark crimson.

Alfred Chantrier-Light rosy amber, petals tubular.

Exposition de Troyes-Flowers large, silvery lilac, early and free, habit compact.

Md. Veuve Macary-Petals large, incurved, lilac rose, centre white quite distinct.

Mrs. Langtry-Pure white of large size. An extra fine sort.

Le Dauphinoise-Quite early and free, yellow ochre color, quite distinct.

Duke of Berwick-Creamy white veined carmine, early and free.

Timbale d'Argent-Anemone, pure white, one of the earliest, extra fine. early.

Eugene Giat-Flowers large and fine, dark red flamed and pointed with orange,

Le Scabieuse-Flowers medium size but freely produced, dark violet purple pointed silvery white, a distinct early bloomer.

La Charmeuse-Very early and free, rich purple tipped with white.

Gloire de Rayonante-Tube shaped, petals deep rose with lilac sliadings, early,

Fernand Feral - Flowers large, rose tipped cliamois, free and early.

Fabias de Maderanaz-Flowers large, purest white.

Frizou-Petals twisted, beautiful canary yellow:

Chas. Delmas-Medium size, Indian red, dwarf.

Louis Wieille-Very early, large flower of quite a distinet rose purple slade.

Lord Byron-Brilliantly marked bronzy red and gold, double and fine. earls.

M. Freeman-Flowers large, beautiful rose color with white centre, dwarf and

Sou de Harlem-Flowers large, orange shaded violet.

Eugene Mezard-Amaranth. reverse of petals violet and white.

Alphonse Karr-Rose pointed white.

$\mathrm{Ka}$ Yeu-Long tubular petals, rose and yellow.

Lividia-Pure white onter petals tubular, free and early. 


\section{GENERAL COLLECTION-Continued.}

Secretaire Barotte-Indian red, reverse yellow, early.

Quadricolor-Flowers full and of finest form, clear rose centre cream streaked with violet and yellow.

Claude Billiard-Flowers large, finely formed, rose lilac. tint.

Lilian B. Bird-A handsone variety, long tubular petals of a delicate tlesh pink

Comte de Moustic-Flowers immense, petals long tubular at bast, reil, bright flame, and salmon, very distinct.

Anna M. Payne-Rose carmine on cream ground, petals twisted, good and parly.

Alcyon-Very large, carmine rose striped white, reverse of petals rose.

Sou. de L'Exp. de Roubaix-A very tine French variety raised by "Sautel." Dark red pointed gold.

Mon. Neville-Very early and fres, salmon changing to rose and white. and fine.

La Triomphante- White suffused with purphish rose, large leep blooms quits early

Gold-A good late yellow, karge and full.

M. Greard-Violet amaranth with paler reverse.

Pelican-Very large pure white. A splendirl late sort.

Bois Rose-Flowers large and frecly produced, blush changing to clear rose.

Lambeth-Flowers large, pure white centre yellow, fwarf and compact.

Edna Craig-Flowers large, pure white. one of the best late hloomers.

Jas. G. Blaine-Deep walnut brown with touches of dark r'rimson, outer petals level. centre slightly incur'verl.

Dr. Sicardon-Flowers large, red with a golden reflex, fine, early.

Md. Feral-Flowers large, rose shaded white.

Miss Mary Morgan-Delicate pink, medium height, late.

Md. Fred'k Minstral-Tender violet and rose, extra fine.

Rooted Cuttings $\$ 1.50$ per 100; $\$ 12.50$ per 1000 .

From pots $2 \frac{1}{2}$ in. $\$ 300$ per I00: $\$ 25.00$.per 1000 .

\section{COLEUS.}

\section{TWO NEW YELLOW COLEUS.}

McGowan's Yellow-A new yellow of a shade between Goklen Bedder and (rolden Verschaffeltii, rel'r slightly marked with reddish purple. A (ompact grower, very short jointed with long leares. A valuable addition to the yellow coleus.

Beauty of Orange-Pure yellow, a shade lighter than Mckowan's Yellow but equally as good in every respect. Both varieties are for bedlling purposes.

Rooted Cuttings $60 \mathrm{cts}$. per doz.; $\$ 3.50$ per I00.

From Pots $2 \frac{1}{2}$ in., \$1.00 per doz.; $\$ 6.00$ per 100

\section{FINE COLEUS.}

Purple Prince

Retta Kirkpatrick

James Barnshaw

Firebrand

Midnight

Starlight

Othello

From Pots $2 \frac{1}{2}$ in., $\$ 3.00$ per I 00 ;
Verschaffeltii, Golden Verschaffeltii, Golden Bedder:

Golden Bedder

Crimson Bedder

Blaze

Louise Beck

Satyr

Miss Publes

Le Kain
Golden Verschaffeltii

Illuminator

John Goode

Royal Mantle

Aline

Saturn

Mole
Verschaffeltii

Alhambra

Crescent

John Dick

Umpire

Neptune

Yedo

Rooted Cuttings 75 cts.per I00: $\$ 6.00$ per 1000 .

From Pots $2 \frac{1}{2}$ in., \$3.00 per I00; $\$ 25.00$ per 1000

Rooted Cuttings $90 \mathrm{cts}$. per I00; $\$ 7.00$ per Iooo.

From Pots $2 \frac{1}{2}$ in., $\$ 3.50$ per 100; $\$ 30.00$ per 1000 .

\section{NOVELTIES IN FUCHSIAS.}

Molesworth-Very free blooming large pure white corolla, habit somewhat like "Storm King" but a much hetter" sort.

Nestor-Corolla single riolett, sepals bright rerl.

Jupiter-Free blooming habit. sepals coral red, double violet blue corolla of perfert forn, neat habit.

Merope-Tube short, large carmine sejuls, large single corolla, dark prune. 


\section{NOVELTIES IN FUCHSIAS-Contiumed.}

Victor de Laprade-Corolla large and very domble pure white veined rose, sepals crimson. A fine variety on the style of "Perle von Brunn" only better. red.

Esperance-The best double variety of the Recartoni type, corolla violet, sepals

Aerostat-Dwarf and bushy, free grower, sepals wine red, corolla single, blue changing to pale lilac.

Md. Millet Robinet-Tube and sepals white, large long single corolla, clear rose, free blooming.

Abbe Garnier-One of the most valuable in the list of Fuchsias. Dwarf, free growing and blooning early, good sized domble corolla, violet blue marked bright rose, sepals reil.

Md. Dieulafoy-Long white tube, sepals pure white, single rose colored corolla.

M. Gindra-Large single corolla, purple marked with carmine.

Cervantes-One of the finest habited Fuchsias grown, sepals bright red, corolla donble rose manre bordered blue.

Pierre Loti-Dwarf free branching habit, tube short, sepals bright red, very large double corolla, rich violet blue.

Rifiand-A rank growing single variety, sepals red, corolla single reddish violet.

Ulysse Trelat-Corolla double, white lined rose, large bright red sepals.

Rooted Cuttings $50 \mathrm{cts}$. per doz.; $\$ 3.00$ per Ioo.

From Pots 2 $\frac{1}{2}$ in., $\$ 1.00$ per doz.; $\$ 6.00$ per roo.

\section{FUCHSIAS.}

Ernest Renan-Tube short rosy white, sepals relieved, large single rose colored corolla, perfect habit, very early.

Clair de Lune-Tube clear orange, sepals recurred, corolla single brilliant orange.

C. N. May-Tube and sepals scarlet, corolla single of a dark prune color.

Louis Mayer-Tnbe and sepals red, corolla domble, purple, sometimes flamed red.

President Carnot-Plants dwarf of excellent free branching habit and free blooning, corolla double violet, tube and sepals wine red.

Edmond About=-An excellent double white variety of the free blooming sort.

Lord Lyons-Sepals recurved, crimson red, large single bell shaped corolla violet prune.

Mrs. E. G. Hill-Flowers large and double of a beautiful form, sepals relieved, corolla red dark red, corolla white.

Gem of Lavington-Large single corolla rosy carmine tinted violet, of strong, healthy habit and free blooming. A good market sort.

Lovliness-Flowers large long, flesh colored sepals, tube short creamy white, corolla large pale violet rose. A fine sort.

M. Berand Massard-Sepals recurved red, corolla double lilac slate color.

Walter Long-Tube and sepals coral red, long single corolla pale carmine bordered white. Early blooming and one of the best.

Rosalind--Tube and sepals white, corolla large and single pale rose bordered briglt carmine. A first-class sort,

Ville de Lyon-Tube large, sepals horizontal, crimson red. Corolla large and double, white veined carmine.

Le Majeitueux - Sepals white, corolla rosy carmine, flowers single, plants vigorous.

Lye's Perfection-Tube creamy white, sepals tinted with flesh color, corolla single, carnine.

Colbert-Sepals salmon rose. corolla dark rose.

Jumna-Sepals cherry, corolla double purple.

Oriflame-Tube and sepals clear crimson, large single corolla, amaranth red.

Rooted Cuttings 50 cts. per doz; $\$ 2.00$ per roo.

From Pots 2 inches, 75 cts. per doz., \$4.00 per roo; \$35 per rooo.

Alice Mary Pearson-Sepals creamy white, tube long, single corolla dark crimson.

Annie Earle-Tube and sepals white, corolla single, carmine. Plants of splendicl habit and free blooming.

Nancy-Sepals large, coral red, corolla double violet blue.

Henry Brooke-Sepals blood red, corolla small, single dark purple.

Enfant Prodigue-Corolla double, violet.

Col. Domine-Sepals red, corolla double, white.

Rosain's Patrie-Plants of the finest habit and a wonderfully free bloomer, and very early. Tube and sepals rosy carmine, corolla double, pure white. A good market sort. 


\section{FUCHSIAS-Continued.}

Abundance-Tube and sepals red, single dark purple corolla, free blooming.

Benjamin Pearson-Tube and sepals rosy rell, corolla single crimson and purple.

Eureka-Tube and sepals pure red, corolla single purple tinterl magenta.

Lovely-Tube and sepals white, corolla singld tinted crimson tinted magenta.

Mon. P. Martignat-Flowers double, corolla rich violet, sepals large, red.

Surprise-Large single flowers, waxy white. corolla nugenta borlered darker.

Nellie-Tube and sepals creamy white, corolla single flesh color shaded maure.

Perle von Brunn-A fine double white.

Pres. Grevy - Corolla double, rosy salmon.

Lustre Improved-Corolla single, scarlet.

Drame-Corolla double, blue.

Elysee-Corolla single, rich violet.

Telegraphe-Corolla single. ricl violet

Mille Jager-The best single rose colored sort.

Joseph Rosain-Corolla double, dark purple striped with rose.

Raphael-Corolla double, blue marked rose.

De Mirble-Large single corolla, rose and violet.

Esmeralda-Corolla large and double, lilac.

Pres. F. Gunther-Large double corolla, lilas.

Sapaly Freres-Corolla riolet and carmine, double.

Teniers-Corolla semi-double, clear violet.

Le Corsaire-Corolla semi-double, carmine double.

Cormorant-Long double corolla, violet.

Duke of Albany-Corolla single. purplish red.

Mazeppa-Corolla single, reddish violet.

Crepuscule-Corolla double, violet.

Lustre.

Speciosa.

Prince Arthur.

Snow White.

Earl of Beaconsfield.

Cecil Glass-Corolla single, rose, tube white.

Rooted Cuttings $\$ 1.50$ per $100 ; \$ 8.00$ to $\$ 12.00$ per 1000 .

From Pots $2 \frac{1}{2}$ in., $\$ 2.50$ per I0o; $\$ 22.50$ per 1000 .

FUCHSIAS UNLA BELLED.

Rooted Cuttings $\$ 1.00$ per I $100 ; \$ 8.00$ per 1000 .

From Pots 21/2 in. \$2.00 per 10o; $\$ 18.50$ per 1000.

\section{DOUHLE IVY LEAF GERANIUMS.}

Giroflee-Flowers very double and of beautiful form, wine red tinted annarantl.

Md. Carnot-Bright amaranth, vermilion centre.

Cardinal Lavigerie-Pale orange red, large trusses.

Gladiateur-Very large perfect flowers of the most perfect form, violet winc.

Cesare Costa-Red shaded magenta, large flowers.

Jacques Callot-Very double flowers, leep violet.

Theodose-Purplish red.

Gallia-Orange red shaded salmon, very large flowers.

Cramoisi-Violet amaranth, large and beautifully formed flowers.

Meteor-Round flowers, cherry red brightened with orange.

Diamante-Mauve shaded lilac.

La Mauve-Bluish mauve veined violet, long petals.

Rooted Cuttings $\$ 3.00$ per Ioo.

From Pots $2 \frac{1}{2}$ in. , $\$ 6.00$ per Ioo.

\section{DOUBKE IVY LEAVED GERANIUMS.}

Veterar-Large trusses of large flowers, semi-double, very bright orange carmine, free flowering.

Gloire de Lorraine--Very large and double rosette shaped flowers of bright clerry red.

La Perle-Rosy lilac, dark veins.

Andre Thuriet-Free flowering and of short jointed habit, large, double cup shaped flowers, reddish violet.

Mad. de Wesch-Large, trusses, flower's double, bright carmine red color. Very beautiful.

De Quatrefages-Flowers full and large, violet rose. 


\section{DOUBLE IVY LEAVED GERANIUMS-Continted.}

Surcouf-Large double flowers, satin rose tinted orange.

Camille Flammarion-Large cup shaped flowers of the finest form, trusses large, deep rose color, very free flowering plants of finest habit.

Abel Carriere-Currant red.

La Rosiere-Immense trusses of large well formed flowers of a rich salmon pink.

De Brazza-Rosy salmon.

Eden Marchii-Beautiful salmon pink.

Md. Thibaut-Very rich deep rose.

La Printemps-Clear salmon.

Exposition de Bayeux-Currant red brown markings, large flowers.

Flambeau-Beautiful garnet red, perfect form, trusses large.

Henri Martin-Flowers full, large imbricated petals, bright satiny rose reflex brighter. ('hoisseul."

Bastien-Lepage-Semi-double rose maure, upper netals lightly reined with purple.

Raphael-Trusses very large, full and of perfect form, salmon rose, centre brighter. A beautiful flower.

Jeanne Gillet-Very dark velvety violet, somewhatstriped dark purple. A beautiful variety.

From Pots $2 \frac{1}{2}$ in., $\$ .00$ per 100.

\section{GERANIUMS.}

As we carry a great variety of Geraniums which are all first-class, good blommers. bearing large trusses and consist of over 250 of the best French noveltiies (doulle and single) we will only be able to supply them in assorted lots true to name."

\section{DOURL,E GERANIUMS.}

La Favorite-White.

Bouguereau-Very soft rose. upper petals marked white.

Md. Doirisse-Rosy vermilion.

Tour Eiffel-Bright orange scarlet.

Catulle Mendes-Purplish rose, upper petals marked white.

Calif Ornie-Yellowish orange color.

M. de Boffley-Bright apricot shaded orange.

L'A bbe Bourgeois-Bright vermilion.

De Lacepede-Rosy flesh color with lilac shadings.

Ernest Bahlson-Flesh color tinted violet.

Md. Clair d'Alins-Salmon rose, white border.

M. Moissan-Orange brick color.

Eclaireur-Brilliant scarlet.

President Carnot-Brilliant deep scarlet.

Dr.Chaumier-Dark violet, upper petals marked with capucine.

Triomphant-Rosy flesh color with salmon markings.

Mon. M. Mathien-Crimson red tinted with magenta, reverse of petals white.

Geronie-Dark violet rose.

Beaute Poiteoine-Brilliant salmon brighter at the edges.

Jean Bouchet-Violet rose.

San Remo-Dark cinnabar red.

Saint Rigamonti-Bright currant red, upper petals orange.

Bonnat-Brilliant carmine rose.

Countesse d'Arlincourt-Bright carmine rose.

Md. la Countesse de Baume-Rose colored.

Baron de Schleinitz-Kose chamois color.

M. Geoffrey de Kergerlay-Clear orange red.

Peintre Carot-Dark purplish red brightened with vermilion.

Champion-Bright amaranth red.

Paul Arene-Creamy white.

Md. Dupoint-Deep scarlet.

Minne-Creamy white with rose shadings.

M. Leon Say-Dark vermilion.

Md. de Benaville-Vivid rese shaded flesh and lilac.

Albert Gaudry-Rose with white centre.

Angra Pequena-Soft red.

Louis Filhol-Bright orange scarletshaded salmon.

Md. la Mise. de Baume-Brilliant magenta rose.

Banes Perfect-Pure white.

Tunisie-Creamy white. 


\section{DOUBLE GERANIUMS-Continued.}

Les Huguenot-Silvery lilac.

Geoffrey Saint Hilaire-Dark red, shaded with violet and orange.

Dernchett-Pearly rose.

M. Jovis-Bright salmon flesh color at the centre bordered with creamy white. purple.

Pres. Dutailly-Dark amaranth bordered with maroon, upper petals marked

M. Preso-Rosy salmon brightened with carmine.

Jules Lartique-Upper petals carmine, lower violet lake.

Contre Admiral Knorr-Cherry shaded with lilac, upper petals distinctly marked with orange.

Centaure-Very brilliant rose.

L' Constable-Bright rose color.

Mon. Caro-Beautiful silvery litac rose.

Mon. David Carmine-Rose, upper petals white.

Price of Labeled Rooted Cuttings in assortment, \$1.50 per 100; \$12 50 per 1000. Price of Labeled from Pots " "\$3.00 per I0o; \$25.00 per Iooo.

\section{DOUBLE GERANIUMS.}

General Grant-Scarlet. Price $\$ 2.00$ per Ioo; $\$ 18.00$ per Iooo.

From Pots $2 \frac{1}{2}$ in., $\$ 3.50$ per $100 ; \$ 30.00$ per 1000 .

Glori La France-Price $\$ 3.00$ per I00; $\$ 25.00$ per 1000 .

Price from Pots 2 1 in., $\$ 6.00$ per I00; $\$ 50.00$ per 1000 .

Summit of Perfection-Price, \$2.00 per I00; \$15.00 per I000.

Price from Pots $2 \frac{1}{2} \mathrm{in}$., $\$ 3.00$ per I00; $\$ 25.00$ per 1000 .

\section{SINGLE GERANIUMS.}

Palisis de L' Industrie-Dark flesh color, white centre surrounded with currant, the coloring being very distinct on the upper petals.

Fournaire-Bright amaranth red.

Protre-Flesh color tinted lilac changing to white and tender rose.

M. Oclavie Deluc-Brilliant orange red.

Therese Mambert-Lilac rose with large white eye.

M. Janssen-Very bright rose, base of upper petals marked white

L'Immortel-Grayish rose, shaded dark lilac at the centre.

Soleil Couchant-Bright and flaming capucine.

Le Grenoblois-Coppery orange color tinted white.

Victorieu Sardou-Violet currant, upper petals marked most distinctly with capucine.

Trophee-Rosy flesh tinted at the centre with lilac changing to dark lilac.

Lumiere Electrique-Rich crimson surrounded with orange.

Univers-Dark crimson scarlet.

L' Virrissel--Salmon flesh brightened with vermilion at the centre.

Queen of Belgium-White.

M. Emile Cailletet-Pure rose, upper petals marked with white

Pink Beauty-Pink.

Brutus-Bright amaranth red.

Chancellor-Very dark crimson.

Sam Smith-Crimson scarlet.

Glorie Poitevine-Brilliant red with white eye.

Mrs. E. G. Hill-Salmon with white centre.

Violet Unique-Pure violet, upper petals marked orange.

Baron du Puynode-Vernilion orange with white eye.

Md. Countess de Montebello-Violef marked orange.

Port Royal-Rosy salmon, centre white.

Fournaise-Brilliant orange scarlet.

Md. Geoffrey du Port-Centre white with salmon rose lordered with white.

Md. La Mise de Mortemart -Satin ross brightened with peach color and flesh centre.

Ed. Pynaert-Brilliant solferino, marked with capucine.

Boncenne-Vermilion with white eye.

Md. Marechal de Grouchy-Salmon with white eye.

Fulminant-Brilliant crimson, white eve.

Fleure Rouge-Flaming orange scarlet.

Md. la Baroune de Fins-Bright rose, upper petals marked white.

Missolonghu-Salmon apricot color strrounde 1 with rose.

Paul Duphis-Rosy white, with a large carmine eye. 


\section{SINGLE GERANIUMS-Continued.}

Protee-Flesh color, tinted lilac changing to white and tender rose.

M. Alfred Maine-Bright red.

Alphonse Daudet-Salmon, very bright at the centre.

Baronne d' Eichthal-Border dark carmine rose, centre violet rose, base of upper petals marlied white.

M. Michel-Violet, upper petals marked white.

M. Leon Croizet-Violet, marked capucine.

Etincelant-Brilliant capucine red.

Ernest Bergman-Rich violet scarlet.

Renaissance-Grayish rose with white centre, upper petals flamed with orange.

Md. La' Countess de Pot-Sälmon flesh color bordered with white.

Md. Laurent-Crimson tinted with violet.

Rooted Cuttings in assortment, \$1.50 per I00; \$12.50 yer I000.

From Pots in assortment, $\$ 3.00$ per $100 ; \$ 25.00$ per 1000 .

\section{DOUBLE GERANIUMS, assorted.}

We have an unequalled collection of varieties of Geraniums composed of varieties of the last four years, they are unlabelled, but are fine stock and are only those sorts that will sell readily.

Rooted Cuttings, \$1.25 per I00; \$II.00 per I000.

From Pots $2 \frac{1}{2}$ in., $\$ 2.50$ per I00; $\$ 20.00$ per 1000

\section{VARIEGATED GERANIUMS.}

$\begin{array}{llll}\text { Happy Thought } & \begin{array}{l}\text { Prince Bismarck } \\ \text { Corinne }\end{array} & \text { Mt. of Snow Italica Unita } & \text { Crystal Palace } \\ \text { Magician } & \text { Effective } & \text { Silver Cord } & \text { Chieftain }\end{array}$
From 21/2 inch Pots, $\$ 4.00$ per Ioo.

Md. Salleroi, \$3.00 per Ioo.

Rose Geranium, $\$ 3.00$ per roo.

For the above variegated geraniums, price is quoted from pots. Rooted Cuttings when we have them at half the above price.

\section{MYYDR A NGEAS.}

Otaska-Rosy carmine flowers.

From $2 \frac{1}{2}$ in. pots, $\$ 4.00$ per Ioo.

\section{SEEDLINGS.}

We will have seedlings in April, transplanted into boxes and pots, of the following: Asters-In variety.

Alyssum-Tom Thumb.

Centurea-Two varieties.

Carnation-Marguerite.

Pyrethrum-Yellow rarieties.

Calendulas.

Lobelia-Crystal Palace Compact. The best for bedding.

Nasturtium-Tom Thumb variẹty. Phlox Drummondii.

Nova Compacta.

From Boxes, $\$ 1.50$ per I00; $\$ 12.50$ per I000.
From Pots $21 / 2$ in., $\$ 3.00$ per I00; $\$ 25.00$ per 1000.

\section{PURE WHITE DAHLIA.}

These are very valuable and useful varieties for cut flowers. coming into blom early, and furnishing an abundance of beautiful pure white flowers of the most perfect form. Will bloom from July until frost.

Marguerite Bruant. White Dove. Cameliaflora.

Plants ready in April. Price from 21/2 inch pots, $\$ 6.00$ per Ioo.

\section{ALTERNAN'THERA.}

Paronchoides Major-Crimson.

Auerea Nava-Yellow.

- Versicolor-Crimson and Pink.

Rooted Cuttings, $75 \mathrm{cts}$. per I00; $\$ 7.00$ per rooo.

From $2 \frac{1}{2}$ in. Pots, $\$ 3.00$ per 100 . 


\section{FEVERFEW.}

Little Gem-The' finest double white.

Rooted Cuttings, $\$ 2.00$ per roo.

From $2 \frac{1}{2}$ in. Pots, $\$ 4.00$ per 100.

\section{HELIO'TROPE.}

Jersey Beauty - The best purple.

Rooted Cuttings, $\$$ r.00 per roo.

From $2 \frac{1}{2}$ in. Pots, $\$ 3.00$ per 100.

\section{SALVIA.}

Salvias Splendens-Scarlet.

Rooted Cuttings $\$$ I.50 per roo.

From $2 \frac{1}{2}$ in. Pots, $\$ 3.00$ per 100 .

\section{ROSES.}

We have six houses of Roses for cut flowers and will have several thousand plants to offer to the trade this spring, good healthy stock of the following rarieties:

Bon Silene.

Le France.

Papa Gontier.

\section{Souvenir D' Un Ami.}

Catherine Mermet.

Perles des Jardins.

Souvenir de Wooten.
Brides.

Niphetos.

Mad. Hoste.

From $21 / 2$ in. pots, $\$ 4.00$ per roc; $\$ 35.00$ per rooo.

From $31 \%$ in. pots, $\$ 7.00$ per I00; $\$ 60.00$ per 1000 .

\section{VERBENAS.}

Our Verbenas comprise the best large flowering sorts and are free from rust and mildew. There is no better stock in the country. All of the leading Mammoth varieties.

Mrs. Cleveland-Pure white.

Defiance-Red, white eye.

Oriflame-Brilliant searlet.

Dawn-Red, extra fine.

Perfection-Extra fine large solid pink.

Venus-Dark pink, showy white eve.

Francis-Very light large pink.

Zebra-Splashed.

Aurora Borealis-Striped.

Prodigy-Rose.

Sapphire-Bleu, large white eye.

La Toska-Reddish carmine.

Summit-Rich purple.

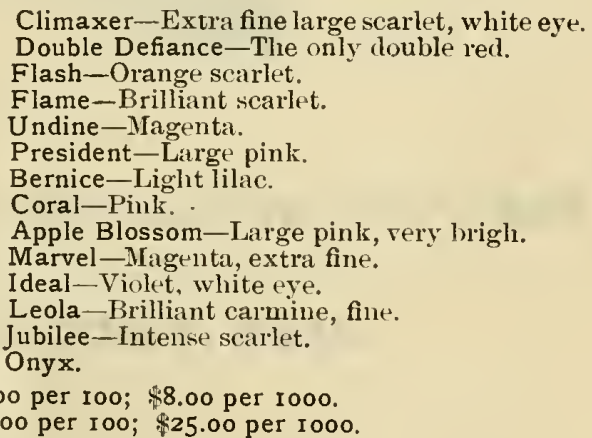

From 21/2 in. Pots, $\$ 3.00$ per 100; $\$ 25.00$ per rooo.

\section{VIOLE'TS.}

Our stock of Violets are in a gool strong. healthy condition, and we will have several thousand rooted rumers this spring, will also have them from pots.

Rooted Runners, $\$$ I.oo per roo; $\$ 8.00$ per rooo.

From Pots $2 \frac{1}{2}$ in., $\$ 2.50$ per roo; $\$ 20.00$ per rooo.

\section{VINCAS.}

Vinca M. Elegantissima and Major.

Rooted Cuttings, $\$ 1.50$ per 100.

From Pots $2 \frac{1}{2}$ in., $\$ 3.00$ per roo.

From Pots 4 in., \$10.00 per Ioo. 


\section{Jthe Flopists' Friend * \\ * Just what vูou Viant.}

STOP YOUR GLASS FROM SLIDING BI USING

$$
\text { E. J. VAN REYPER'S }
$$

PERFEGTI GLAZIERPS' DOINMS.

ENDORSED BY

IEADIXG

FLORISTS.

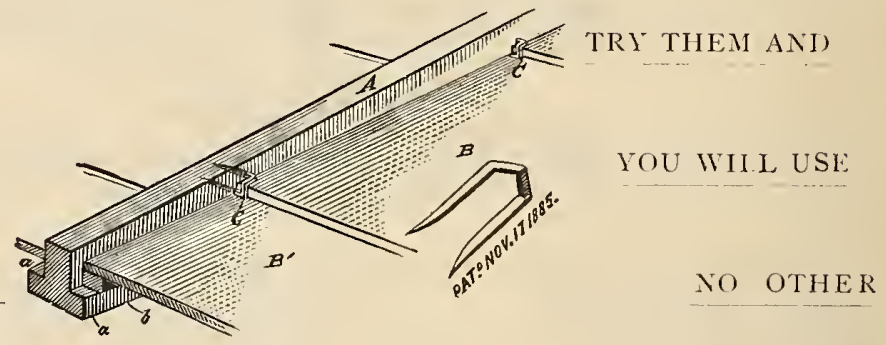

Made of Steel Wire and Galvanized. No Rights and Lefts.

OVER 5,000,000 IN USE.

Manufactured by

ESSEX HEIGHTS FLORAL CO.

BELLEVILLE, NEW JERSEY. 
The past winter we had occasion to grlaze some houses and laid the glass without putty, fastening it with E. J. Van Reyper's Perfect Glaziers' Points; after the house was entirely glazed we used twothirds mixed paint, and one-third puttyin Scollay's Putty Bulb, running it down over the glass where the sash-bar meets, thus making a perfectly tight house, and we have not had a cracked light of glass on it.

Having an establishment of nearly 60,000 sq. ft. on which these points are in use, we can guarantee satisfaction.

Price per box of 1,000 by mail, 65 cents.

In lots of 5,000 by express, 55 cents.

Pincers for driving the points, 40 cents.

By mail, 50 cents.

Send two cent stamp for sample.

For sale by all Seedsmen, Hardware Dealers and Florists' Supply stores throughout the United States. If you fail to procure them send direct to

\section{THE ESSEX HEIGHTS FLORAL CO.,}

Belleville, $\mathbf{N} \cdot \mathbf{J}$.

AGENT FOR THE DOMINION OF CANADA.

\section{J. G. SIMIIERS, \\ Ir4 East King St., \\ Ontario.}

For sale by the following Seedsmen and Hardware Dealers:

Peter Henderson \& Co, 35 and 37 Cortlandt St., New York Cíty.

Wr. Elliott \& Sons, 54 and 56 Dey St., New York City.

Weber \& DoN, 114 Cliambers St., New York City.

SCHLeGel \& Fottler, 26 South Market St., Boston, Mass.

Henry A. Dreer, 714 Chestnut St., Philadelphia, Pa.

Cruzer, Buffat \& Buckwell, 34 Market Square, Knoxville, Tenn,

Wy. C. Beckert, 47 Federal St., Allegheny, Pa.

J. A. Smulers, 14 i East King St., Toronto, Ontario, Canada.

Geo. C. Barker \& Sox, 99 Spring St., Newport, R. I.

Clemuexs Vonnegut, $18 t$ and 186 East Washington St., Indianapolis, Indiana.

A. D. Perri \& Co., $21 \%$ Warren St., Syracuse, N. X.

Currie Bros., Milwaukee, Wis.

C. Morqans' Sons, 56 Market St., Wilkesbarre, Pa.

P. M. Herron, 34 and 36 Genessee St., A uburn, N. Y.

J. C. Jerferis, West Grove, Pa.

C. Noellixg, Louisville, Ky.

Evw. S. Schmid, 71212 th St., N. W., Washington, D. C. 
$W^{\mathrm{E}}$

E take pleasure in calling the attention of the public, and Florists in particular, to the most perfect article in the line of Glaziers' Points that has ever been invented.

It is the cheapest, most durable, and the only reliable Glaziers' Point on the market, being made of steel wire, with two points, when driven in the sash bar it will stay there; not like other Points that bend in the middle when you are driving them.

Glaziers' Points that are cut in a triangular form when driven into the sash bar, necessarily make a large hole and the points are bound to work out of their places, but we can guarantee that “The E. J. Van Reyper's Perfect Glaziers' Points" will never work out, and more that this, you will not be annoyed by the use of Rights and Lefts, which is a great saving of time.

If a light of glass should get broken the point may be easily forced out by the use of a chisel. Place the chisel on the sash-bar. back of the tong and the point will come out in perfect condition to use again. They do not take up any more space on top of the glass than the brads or shoe nails.

“The E. J. Van Reyper's Perfect Glaziers' Points" cost a trifle more, but are the clecapest in the end, as their is no waste. Not like the Zinc Points, more rights than there are lefts to match.

It will cost to glaze a hoise $18 \times 100$ feet with $12 \times 14$ glass, less than $\$ 2.40$ by using E. J. Van Reyper's Perfect Glaziers' Points, and save more than that amount in time and labor. You will never be annoyed by sliding glass, and will have no more repairing on your sash or roof.

These points are easily driven with a chisel, but by using our Pincers three times as many can be driven in a day. The pincers are hollowed out to receive the glazier's point and slant up with the roof, one claw grips the sash-bar and the other the point, so that there is no shaking like there is when you drive against the sash-bar.

Remember that you can use them on either side of the sashbar.

No Rights and Lefts.

We have sent out this season over $5,000,000$ through the United States and Canada. 
TESIIMOIVIAIS.

\section{E. J. Van Reyper's Perfect Glazier's Points.}

The following are a few of unsoliciced testimonials which we have many of :

\author{
Kichmond, Ind., Sept. 3, 1891. \\ Eissex Heigats fentat Co., \\ (ientlemen:-l'tease send us 10,000 of your \\ P'atent Giaziers' l'oints by express; we find w' \\ need those to complete our houses; the poilts \\ work nicety. \\ Yonrs ete.

$$
\text { E. G. HHLL \& CO. }
$$

Southumptou, N. Y., sept. 2: 1891. Lissex heiguts Florat, Co.,

Geutlemen:-Plense send inmediately log mail Iwo more hoxes of Perteet Glaziers' Poiuts, I like thern very untrh anil will use uo others.

WM. F. H.ISEY.

Ksiex Heights Florac Co.,

Scrastou, P:ı., Nну 4, I891.

Gentlemell :-Pleasé send me 2,000 nure Glayiers' Points. I havensed a great many glazit'r's' points bnt I never tound any that fills the bill like yours.

$$
\text { Yours, R. W. PALIKR. }
$$

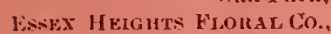

Oalk Purk, IHs., A ug. 29, 1841.

(ientlemen:-Please send me two thousaurl more of F. J. Vau keypers' Points by mail. fousilel them very good. Yours truly,

\section{A. PEDERSEN.}

Essex Hetghts FonaL Co.,

Shelbyville, Ind., Nov. 2, 1891.

Gents:--Enclosed druft for Three Dollars and Five Cents for Perfect Glaziers' Points. Please send at once, 'The Perfect Giaziers' l'oints arc just I the thing for glazing greenhouse glass ant hot bed sash. Yonrs truly, W. F, I.AW.

Norristown, l'u.

l'lense send to my order one thousand of your glazier's' points. I am so detighted with then that I whl never glaze with any other.

respectfully Yours, JOHN CUNXINGHAM.
Situly Hitt Nursery, Iakewood, N. J. Essex Hexgme flonal Co.,

Gentlemen:- I have been using your Glaziers" Points and like them very well. You may send ne 4,000 more. Yours tiuty.

A. S. MAC BEAN.

Columbus, ソ., Dec. 4, 1891.

ESSEX II EIGHTS FlontL Co.

Gentlemen:-Please send ile llve thousand Points and one pineers, they are the best article I ever used. Yourstiuly, s. F. STEPIIENS.

Brookiteld, . Yto., Sept. 12, 1891.

Essex If eights Floral Co.,

Gentlemen:-Please send ine two boxes mor: of Perfeet Glaziers' Points at nuce. 'They are: just the right thing to have for grecnhouses glazing.

JOSEPH GAMHJ.E.

Mitwulke, $W$ is., oct. $6,18: 1$. Essex H hights Florar Co.,

Gentlement-Please send ine 2,000 of your Perfect Giazier's' Points. I was pleaser very nuch with those I received.

Very respectfulis, FIRED. SASSH.

Gloneuster, Mass., Sept., 26, 1891.

Essex If migats Floral Co.,

Gentlemeu:-Received the two boxes of points and have used them. They are the begt thing 1 ever used, have showu them to others and think you will get orders from them.

GEO. HI. PUICTHER. 


\section{JAMES PURDY,}

Wholesale and Commission Dealer in

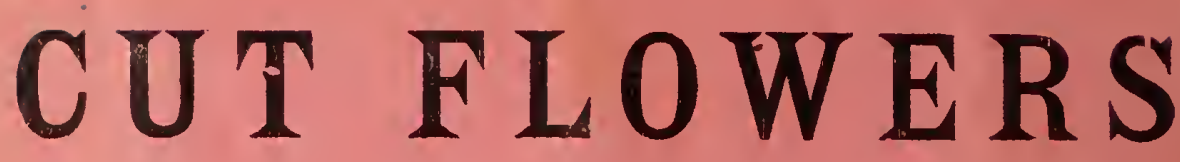

My Specialties are the Finest

\section{$\underline{\text { Roses, Carnations, Violets, se. }}$}

Florists wanting good stock, carefully packed and shipped on time, will make no mistake if they place their order with mc.

Any flowers not on hand will be procured if in market.

Return telegram is sent immediately when it is impossible to fill order.

Having an experience of over 15 years as a wholesale Florist and Shipper I will guarantee satisfaction to all my former patrons as well as new ones trusting their orders to me.

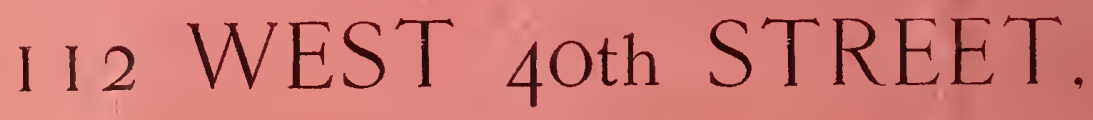

NEW YORK.

a

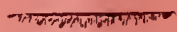

N.B.--CONSIGNMENTS FROM GROWERS SOLICITED. 